Мельничук Ольга Вікторівна кандидат історичних наук, завідувач кафедри документознавства та інформаційної діяльності, ПВНЗ «Академія рекреаційних технологій і права», вул. Карбишева, 2, м. Луцьк, 43023, тел.: (068) 845-23-84, e-mail: olga_melnychuk@ukr.net; https://orcid.org/0000-0001-5852-6433

\title{
ДЕРЖАВНЕ РЕГУЛЮВАННЯ КНИГОВИДАВНИЧОЇ ДІЯЛЬНОСТІ В УКРАЇНІ: ОРГАНІЗАЦІЙНО-ПРАВОВИЙ АСПЕКТ
}

Анотація. Статтю присвячено теоретичним i практичним проблемам організаційного та правового забезпечення управління в сфері видавничої справи. Необхідність пріоритетної підтримки 3 боку держави саме книговидавничої діяльності визначається значенням книги на сучасному етапі формування постіндустріального суспільства. Поступальний розвиток книговидавництва значною мірою залежить від результативного державного регулювання, яке здійснюються відповідними уповноваженими суб'єктами за допомогою визначених правових засобів. У статті розглянуто законодавство про книговидавничу діяльність як сукупність нормативно-правових актів, а саме: Конституції України, законів України та підзаконних актів. У науковій розвідці акцентується увага на визначенні переліку основоположних нормативноправових актів, де відображено норми, якими врегульовано суспільні відносини в книговидавничій сфері. Окрім того, досліджено їхні окремі положення й надано пропозиції щодо вдосконалення чинного законодавства 3 питань книговидавничої та книгорозповсюджувальної діяльності 3 метою подальшого використання в практичній площині для отримання належних результатів. Наукове дослідження грунтовно розкриває основний зміст державного управління книговидавничою діяльністю й пропонує практичні рекомендації щодо вдосконалення даного процесу. У роботі запропоновано шляхи вдосконалення державного регулювання книговидання в Україні як складової інформаційного простору. Проаналізовано законодавчі проблеми національного книговидання на сучасному етапі. Визначено основні шляхи підвищення ефективності управління видавничою справою в Україні. Узагальнено пропозиції щодо вдосконалення забезпечення на державному рівні регулювання книговидавничої діяльності в Україні. 3 метою поліпшення роботи галузі сформульовано пропозиції щодо зміни чинного законодавства відносно стратегічно значущого в контексті побудови інформаційного суспільства електронного книговидання. 
Ключові слова: книжковий ринок, видавнича справа, книгорозповсюдження, правове забезпечення, державне регулювання.

Melnychuk Olha Viktorivna Candidate of Historical Sciences, Head of the Department of Scientific Discipline of Documentation and Information Technologies of Private Higher Education Institution "Academy of Recreational Technologies and Law”, Karbysheva St., 2, Lutsk, 43023, tel.: (068) 845-23-84, e-mail: olga_melnychuk@ukr.net; https://orcid.org/0000-0001-5852-6433

\section{ORGANIZATIONAL AND LEGAL ASPECTS OF STATE REGULATION OF BOOK-PUBLISHING ACTIVITIES}

Abstract. The article is devoted to the theoretical and practical problems of the organizational and legal providing the management in the book-publishing relations. Book-publishing is a decisive factor in the progress of society and source of economic growth of the state. It is undeniable that in the modern world the value of book prompted the importance of reliable and substantial state support of this sphere. State establishes the recognition of book-publishing as a socially significant industry and the maintenance of book as the priority state task. In the article the legislation on bookpublishing activities are represented normative and legal acts, namely: the Constitution of Ukraine, the laws and the subordinate acts of Ukraine. The focus is determined on the list of basic legal acts, which were reflected the standarts that regulate social relations in the sphere of book-publishing. In addition, for obtaining the appropriate results, were conducted researches of their certain provisions and submitted proposals for improvement of the current legislation on issues of book-publishing and books' distribution activity with the purpose of their further use in a practical way. Scientific research thoroughly reveals the main content of the public administration of the bookpublishing activities and offers practical recommendations for improving the process. The paper covers ways to improve public regulation of book publishing in Ukraine as a part of the information field. It also presents the legal problems of national publishing at the present stage. Main ways of the publishing management effectiveness' development are determined. The proposals concerning improvement of the public regulation of the book-publishing activity in Ukraine have been developed. To improve the work of the field, certain suggestions were made on changing current legislations regarding E-book publishing which are of strategic importance in the context of new information society development.

Keywords: book market, book-publishing activity, books' distribution, legal providing, state regulation. 
Постановка проблеми. Незважаючи на зростання використання новітніх інформаційних технологій в різних суспільних галузях, книга все ж залишається чи не найважливішим засобом передачі інформації, а друковане слово - чинником духовного та культурного поступу нації. В умовах сьогодення неоціненного значення набуває переосмислення здобутків та втрат вітчизняної видавничої галузі у зв’язку з гібридною агресією РФ в Україну. Адже книжковий ринок $\epsilon$ складовою не лише економічного розвитку, а й інформаційної безпеки країни. У зв'язку 3 гуманітарною експансією країни-агресора на українські землі актуальним постає вивчення тенденцій розвитку книговидавництва в Україні, вироблення рекомендацій для поліпшення стану галузі, оновлення організаційноправових рамок у зв'язку з потребами часу та задля належної протидії російській інформаційній агресивній політиці на вищому державному рівні. Разом 3 тим, українське законодавство слід впорядкувати та оновити відповідно із інформаційно-технологічними новаціями, які з'явилися на книжковому ринку України. Усе вище зазначене й зумовлює актуальність даної наукової розвідки.

Аналіз останніх досліджень. Тенденції розвитку сучасного українського книговидавництва й частково державне регулювання видавничої сфери в Україні досліджували К. Казак [8], І. Копистинська [9], Г. Овсієнко-Миронова [10], А. Садовська [15] та ін. Однак комплексне дослідження змісту та проблем нормативно-правового регулювання книговидавничої діяльності в Україні відсутнє.

Мета статті - здійснити грунтовний аналіз стану організаційно-правових основ державного регулювання книговидання в Україні на сучасному етапі.

Виклад основного матеріалу. Із відновленням незалежності України на поч. 1990-х рр. розпочато розбудову національних державних інституцій та законодавства у книговидавничій сфері. Загалом державне регулювання у цій галузі включає економічні, соціальні, правові та низку інших заходів, які спрямовуються на виконання запитів держави та соціуму в інформаційновидавничій продукції. Запроваджені державою організаційно-правові рамки повинні формувати позитивні умови для існування галузі, при цьому водночас не втручаючись будь-яким чином у процес продукування творів [15, с. 226].

Державою використовуються наступні регулюючі механізми: антимонопольна політика, податкові важелі та низка форм правового впливу [8, с. 159]. Серед інших застосовуваних засобів - стандартизація, державне замовлення, дотації, тарифно-цінові важелі, субсидування тощо [15, с. 227]. Вагому роль займає нормативно-правове регулювання книговидавничої галузі.

В Україні діяльність суб'єктів книговидавничої справи регулюється Конституцією України, законами та іншими нормативно-правовими вітчизняними та міжнародними актами. Водночас через специфічні 
характеристики книговидавництва регулювання галузі здійснюється цивільним, кримінальним, адміністративним, господарським та іншими сферами права. Проте одним із основоположних у цій галузі нормативних актів є Закон України «Про друковані засоби масової інформації (пресу) в Україні» у 1992 р. [6]. На думку деяких дослідників, фундаментальним у системі української книговидавничої галузі став Закон України «Про інформацію» (1992) [7]. Саме останній створив основу для інформаційної діяльності Україні загалом та книговидавництва зокрема [16, с. 144].

Важливими для розбудови вітчизняної видавничої справи стало набуття чинності Законами України «Про доступ до публічної інформації», «Про обов'язковий примірник документів», «Про державну підтримку книговидавничої справи в Україні», «Про оренду державного та комунального майна» щодо книговидавничої справи» тощо; Указів Президента України «Про додаткові заходи щодо державної підтримки культури і мистецтва в Україні», «Про деякі заходи з дерегулювання підприємницької діяльності» тощо; постанов Кабінету Міністрів України «Про затвердження мінімальних ставок винагороди (роялті) за використання об’єктів авторського права і суміжних прав», «Про Державний реєстр видавців, виготівників i розповсюджувачів видавничої продукції» та багато інших [8, с. 102].

Організаційно-правові та інституційні аспекти охорони авторського права врегульовано Законом України «Про авторське право та суміжні права» (1994) [3]. У 1997 р. набув чинності Закон України «Про видавничу справу» [4], який сформував основи для створення та розповсюдження книговидавничої продукції в державі. Задля відповідності вимогам часу зазначений Закон постійно вдосконалюється через внесення доповнень до нього (упродовж 2002-2016 рр. було внесено 14 змін окремих його положень) [8, с. 102]. Згідно даного документу, політика книговидавничої сфери формується законодавцем (Верховною Радою України), а також окреслено основні напрямки державного регулювання цієї галузі. Серед іншого, Законом задекларовано насамперед підтримку розвитку національного книговидавництва, а також україномовних публікацій для задоволення потреб освітніх, наукових та інших закладів [4; 8, с. 163].

Фахівці вважають, що даний нормативно-правовий акт не передбачив, а тому - й не створює передумов для вирішення гострих проблем, 3 якими зіштовхуються вітчизняні видавці. Наприклад, 3 часу затвердження даним документом відзначалася можливість видавництва книг російською мовою для відповідно потреб російського населення в нашій країні. Така норма закону відповідно вплинула на наявність високої частки російськомовних публікацій на вітчизняному ринку, що створювало велику конкуренцію українським видавцям. Відповідні зміни до Закону були внесені лише із початком російської гібридної 
агресії у 2014 р. [16, с. 144].

Разом 3 тим, з часу набуття чинності вищеокресленого Закону і дотепер на вищому державному рівні так i не було затверджено програм чи інших документів, які суттєво вплинули б на піднесення української книговидавничої галузі. Так, затвердження програми «Українська книга» (3 1997 р.) у сфері державного замовлення видавництва книг на конкурсній основі значно не покращила ситуацію. Загалом програма не лише покликана підтримувати вітчизняних книговидавців, а й сприяти книгорозповсюдженню українських книг по бібліотеках. Попри наявність позитивних аспектів програми слід відзначити й низку їі недоліків. Так, фахівці відзначають відсутність чіткої концепції програми, розмиті параметри та критерії відбору творів для публікації, націленість на незначну кількість видавництв тощо, що у підсумку дає змогу стверджувати про відсутність національного масштабу акції, неефективність витрачання державного фінансування та загалом подальшої діяльності у цьому напрямку. Низку проблем українського книжкового ринку вирішить не така фактично одноразова акція, а комплекс заходів та їх поступове впровадження у вітчизняній видавничій справі $[14$, с. 9].

Подолати кризову ситуацію у вітчизняному книговидавництві був покликаний Закон України «Про державну підтримку книговидавничої справи в Україні» (2003). Після затвердження він багато разів зазнавав змін, втратив чинність та потім відновив іï у 2020 р. [5]. Можна стверджувати, що цей документ насправді не спричинив кардинальних змін на вітчизняному книжковому ринку, про що свідчать статистичні дані. Так, тираж видань у 2005 р. складав бл.54 млн. примірників, а у 2014 р. - бл.55 млн. Науковці та практики вважають, що державне регулювання даної галузі є дуже слабким. Адже держава не застосовує навіть існуючі в ii арсеналі інструменти, а також не залучає передові методи керування книговидавничою галуззю [8, с. 170].

Ситуація на українському книжковому ринку обговорювалася на парламентських слуханнях «Проблеми розвитку українського книговидавництва, книгорозповсюдження та перспективи підтримки книгочитання в Україні» (2013). Зокрема було відзначено необхідність гідної належної державної підтримки у зазначених напрямках, а також про потребу розвивати електронне видавництво книг, комплектування бібліотечних установ тощо [11, с. 852]. У цьому ж році затверджено низку нормативно-правових документів задля запровадження позитивних змін у даній галузі [15, с. 225].

Окремими складовими компонентами нормативної бази України є програми розвитку книговидавництва та книгорозповсюдження. Так, у 2013 р. Кабінет Міністрів України схвалив «Концепцію Державної цільової програми популяризації видавничої продукції та читання на 2014-2018 рp.»[13]. Даним 
документом передбачалися співпраця та можливість долучення до проєктів державних та зацікавлених структур, спільна діяльність у формі підготовки та трансляції телерадіопрограм та інформаційної продукції, виставково-ярмаркової діяльності тощо. Проте задекларовані в документі заходи залишилися нереалізованими через втратою ним чинності вже у 2014 р. До того ж наявні статистичні відомості свідчать про тогочасне зменшення фінансування галузі 3 державного бюджету (відповідно з бл. 1 млрд. грн. у 2009-2012 рр. до 0,55 млрд.у 2014-2018pp) [17, с. 75].

Основні напрямки реалізації інформаційної політики України визначалися такими концептуальними документами, як: «Державна програма розвитку національного книговидання i преси на період до 2000 р.», «Концепція відновлення всеукраїнської книготорговельної мережі», «Концепція державної цільової програми популяризації вітчизняної книговидавничої продукції на 20092012 рр.» тощо. Задля покращення умов розвитку вітчизняного книговидавництва було підписано Президентом України низку указів, серед яких: «Про деякі заходи 3 розвитку книговидавничої справи в Україні» (задекларовано створення міжвідомчої комісії з питань розвитку видання та розповсюдження книг); «Про проведення в Україні у 2007 р. Року української книги» (передбачалося розробити державну промоційну програму книги, й насамперед - серед молоді); «Про деякі заходи щодо державної підтримки книговидавничої справи i популяризації читання в Україні» та низка ін. [8, с. 102]. Постановою «Про затвердження Порядку визначення обсягу книжкової продукції державною мовою...» (2009) створювалася система визначення обов'язкового тиражу україномовної продукції на книжковому ринку. Інституції 3 книгорозповсюдження повинні були постачати на ринок не менше 50\% україномовних друків від загального обсягу продукції [12].

Дослідники відзначають низький рівень державної підтримки не лише україномовної книги, а й стимулювання державою перекладу літератури на українську мову. Сьогодні можна стверджувати про існування перекладацьких програм та премій, які ініціюють закордонні інституції, та відсутність таких 3 українського боку. Недостатніми є заходи щодо контролю проведених заходів для відродження української книги. Загалом статистичні відомості у книговиробництві в Україні є невтішними (для пор.: у 1990 р. продукувалося 3,27 книги на особу; у 2013 р. - одна книга на мешканця України) [14, с. 10].

На сучасному етапі на українському книжковому ринку присутня ще одна проблема - існування великої частки російськомовних видань. Введення на державному рівні квот на україномовний друк продовжує ігноруватися суб’єктами книжкового ринку. Реальні зміни можна зробити завдяки практичному використанню державою регуляторних методів і засобів. Зокрема у 
Законі України «Про видавничу справу» серед іншого вказано про можливість отримання видавничо-поліграфічними підприємствами пільг при сплаті податкових зборів. Проте відсутність відображення даного та багатьох інших положень в підзаконних нормативно-правових актах та розробка відповідних регулюючих механізмів свідчить про декларативний характер низки норм чинного законодавства України $[14$, с. 2]. У цьому контексті слід відзначити Закон України «Про підтримку книговидавничої справи» (2002). Зокрема стверджувалося тимчасове звільнення книговидавництв від низки податкових платежів. Проте про україномовні книги тут уже ніяких згадок не знаходимо, що у підсумку лише вплинуло на збільшення тиражів російськомовної літератури, а також відкриття російськими видавництвами дочірніх представництв на території України [14, с. 4].

Значні трансформації в гуманітарній політиці України розпочалися iз початком російської агресії у 2014 р. Задля української національної безпеки необхідно було вирішити й проблему поширення в Україні російськомовних видань 3 РФ. Лише у 2016 р. Верховна Рада України внесла низку змін та поправок, які стосувалися обмежень ввозу на українську територію іноземних друків антиукраїнського характеру. 32017 р. усі російськомовні видання обов'язково почали проходити перевірку фахівцями Держкомтелерадіо України. Спершу такі заходи створювали певні труднощі при ввезенні російськомовних праць в Україну. 3 іншого боку, загострювалася проблема нелегального ввезення друкованої продукції з РФ. Тому з березня 2018 р. у практику вводяться такі заходи, як: конфіскація контрабандних друків, накладання штрафів на розповсюджувачів такої продукції в Україні. Проте загалом ці заходи не в достатній мірі $є$ дієвими. Вбачається необхідним на державному рівні увести законодавчі та практичні обмежувальні механізми поширення видань з Росії як країни-агресора, і в першу чергу - на східних та південних землях України [1].

Окрім вже перелічених до нормативно-правового регулювання книговидавництва в Україні слід віднести низку рішень Конституційного та інших судів України; локальні корпоративні норми, якими врегульовано права та обов'язки членів книговидавничих та книгорозповсюджувальних інституцій, у випадку порушення яких настає юридична відповідальність [8, с. 102].

Ще однією складовою правового регулювання видавничої галузі є низка стандартів та інших нормативних документів у сфері видавництва. Так, видавці повинні дотримуватись вимог стандартів України у цій галузі: ДСТУ 3017-95 «Видання. Основні види. Терміни та визначення»; ДСТУ ГОСТ 7.80:2007 «Система стандартів з інформації, бібліотечної та видавничої справи. Бібліографічний запис. Заголовок. Загальні вимоги та правила складання»; ДСТУ ГОСТ 7.1:2006 «Система стандартів 3 інформації, бібліотечної та видавничої 
справи. Бібліографічний запис. Бібліографічний опис. Загальні вимоги та правила складання»; ДСТУ ГОСТ 7.9:2009 «Система стандартів з інформації, бібліотечної та видавничої справи. Реферат і анотація. Загальні вимоги»; ДСТУ ГОСТ 7.84:2008 «Система стандартів з інформації, бібліотечної та видавничої справи. Видання. Обкладинки та палітурки. Загальні вимоги та правила оформлення»; ДСТУ 7342:2013 «Інформація та документація. Видавнича анотація. Правила складання та подання у виданнях», ДСТУ 7157:2010 «Видання електронні. Основні види та вихідні відомості» та ін.[2]. Проте дослідження дотримання таких норм у практичній площині свідчить про те, що значна частина редакцій не дотримується чинних стандартів у видавничій галузі. У підсумку це призводить до оформлення значної частини публікацій з помилками [8, с. 103].

Зауважимо, що творення організаційно-правового фундаменту для функціонування видавничої справи в Україні здійснювалося суперечливо, не завжди послідовно і своєчасно. Сьогодні на вищому державному рівні здійснюються певні спроби реформування, які все ж мають безсистемний та хаотичний характер. Низка важливих аспектів видавничої діяльності в Україні опинилися за межами правового регулювання. Водночас окремі нормативноправові акти не лише не сприяли, а й навіть завдавали шкоди для розвитку галузі. Прикладом може бути Указ Президента України «Про ліквідацію обласних книготорговельних об'єднань і об'єднання «Укркнига»...» (1992), яким зруйновано тоді ще діючу систему книжкової торгівлі й загалом загострено кризу книговидання в Україні. В умовах тогочасної відсутності правового регулювання податкової політики та видавничої галузі загалом разом із вищезазначеними тенденціями видавнича продукція опинилася на одному рівні з творами масового використання [8, с. 31].

Отож, для розвитку видавничої справи потрібно затверджувати не лише нормативні акти, а й розробити та послідовно реалізовувати стратегію розвитку галузі. Відсутність конкретних цілей та одночасне прийняття масиву законодавчих документів не покращили кардинальним чином стану українського книговидавництва та сферу книгорозповсюдження [8, с. 32]. Вбачається найбільш оптимальним створити єдину нормативно-правову базу регулювання книжкового ринку, упорядкувати чинні законодавчі норми, а також постійно і системно вивчати поточний стан розвитку галузі. Дослідниками навіть висловлюється думка про нерозуміння державою іiі ролі у побудові дієвих механізмів для розвитку книговидавництва, створення яких у перспективі стане вагомим вкладом в економічний та духовний поступ нації [14, c. 2]. Слід увести оптимальний, а не максимальний обсяг нормативно-правових актів, і лише у тих галузях, де це потрібно. Також слід уніфікувати понятійний апарат у видавничій галузі та надалі увести його у вітчизняне законодавство [8, с. 59]. 
Чинне нормативно-правове регулювання характеризується майже повною відсутністю законодавства у сфері електронного книговидання. Сьогодні книговидавнича галузь доповнена такими новими поняттями як електронні книги та бібліотеки, мережа Інтернет та ін. Тому дана галузь сьогодні потребує урегулювання низки аспектів електронного книговидання (захисту авторських прав у мережі Інтернет тощо). Вбачається необхідним прийняття законодавчого документа, який регулював би електронний книжковий ринок, заклав основоположні рамки охорони інтелектуальних прав авторів та видавців, запровадив єдине тлумачення та використання низки категорій (електронний документ, електронний часопис тощо) [1].

Юридичного врегулювання на вищому рівні потребують аспекти обліку активних видавців в Україні, щорічного обсягу видання книг, здійснення статистичного аналізу книговидавництва та книгорозповсюдження. Реальний стан активності українських книговидавців фактично ускладнений для дослідження через здійснення поліграфічної діяльності низкою суб'єктів лише «на папері» або й зовсім припинення своєї діяльності без анулювання відповідних свідоцтв на виконання робіт. Ускладнене вивчення реально виданих в Україні публікацій й через недотримання бл. чверті усіх видавців Закону України «Про обов'язковий примірник видань», неправдиві відомості у вихідних даних видань стосовно тиражу тощо. Тому цей аспект потребує додаткового врегулювання. Загалом об'єктивних та достовірних джерел про різні напрямки розвитку книговидавничої галузі в Україні відсутні, що надалі ускладнює використання відомостей аналітиками та державними управлінцями для вироблення відповідних рішень для вдосконалення законодавчої бази у цій сфері $[8$, с. $170 ; 9$, с. 10$]$.

Перед державою сьогодні постають інші невирішені проблеми: створення умов для прозорого проведення конкурсних відборів публікацій за державним замовленням, приведення національних стандартів у відповідність до міжнародних, активізація непрямих регуляторів стимулювання попиту на друковану продукцію (через регулювання рівня доходу громадян, кваліфікації кадрів, популяризації читання, створення інфраструктури тощо) [17, с. 74]. Фахівці вважають, що покращення управління видавничою галуззю слід здійснювати через законодавчі нововведення у податковому та митному законодавстві. Негативно на розвиток поліграфічних підприємств впливають правопорушення у сфері авторських та суміжних прав (наприклад, несанкціоноване виготовлення і поширення книг), а також ввезення імпортних друків та поліграфічної продукції, контрабанда тощо. Усе це потребує додаткових організаційно-правових заходів 3 боку держави задля захисту українських видавців та авторів [17, с. 74-75]. 
Окремим, проте не менш важливим на книжковому ринку $\epsilon$ сфера книгорозповсюдження, яка потребує належного державного регулювання. Чи не найбільшою проблемою сьогодні $\epsilon$ недоступність для читачів україномовних видань. У зв’язку з цим слід об’єднати зусилля держави та недержавних установ задля розвитку мережі книгарень та їх належної фінансової, організаційної та ін. підтримки, запровадження обов'язкового дотримання стандартів та інших норм видавцями, здійснення комплексних досліджень цього напрямку для напрацювання рекомендацій i подальшого їх впровадження у практичній площині [14, с. 5].

У зв'язку 3 вище окресленими аспектами постає потреба реформування органів виконавчої влади, які здійснюють безпосереднє керівництво галуззю (Державний комітет інформаційної політики, телебачення та радіомовлення, обласні управління 3 питань ЗМІ у складі державних адміністрацій). Фахівці вважають, що для результативного керівництва галуззю на місцях найкраще було б передати значну частину повноважень органам місцевого самоврядування [8, с. 156]. Загалом органи державного управління видавничою галуззю в Україні повинні враховувати суспільні потреби та вимоги часу й відповідно оптимізувати фінансування галузі з державного бюджету, провадити активну інформаційнопросвітницьку діяльність. Проте все ж для цього слід розробити та реалізовувати цілеспрямовану державну політику розвитку української книги [10, с. 10].

Висновки. Видавнича галузь в Україні з поч. 1990-х рр. і до сьогодення пройшла складний шлях свого становлення. Нормативно-правову базу книговидавничої діяльності заклали Закони України «Про друковані засоби масової інформації (пресу) в Україні» (1992), «Про авторське право і суміжні права» (1993), «Про видавничу справу» (1997), «Про державну підтримку книговидавничої справи в Україні» (2003) та багато інших. Дослідники та практики вважають українське законодавство недосконалим для розвитку книговидання. Відсутність цілеспрямованої та дієвої політики держави у сфері книговидавництва, державної фінансової та організаційно-правової підтримки вітчизняних видавництв негативно впливають на і без того катастрофічний стан українського книжкового ринку. Сьогодні чинна нормативно-правова база не відповідає реальним культурним, науково-освітнім та іншим потребам українського суспільства. Головними проблемами українського книговидавництва залишаються недосконала законодавча база для створення $\mathrm{i}$ поширення україномовних видань, недостатня державна підтримка у популяризації української книги, прогалина у законодавстві щодо електронного книговидання та книгорозповсюдження тощо. 


\section{Jimepamypa:}

1. Актуальні проблеми ринку книжкової продукції в Україні в контексті завдань гуманітарної політики: аналітична записка. Підгот. О. Ю. Михайлова. Офіційний вебсайт НІСД. 2019. квітень. URL: https://niss.gov.ua/doslidzhennya/gumanitarniy-rozvitok/aktualniproblemi-rinku-knizhkovoi-produkcii-v-ukraini-v

2. Дурняк Б.В. та ін. Стандарти в поліграфії та видавничій справі: довідник. Львів: Видво Укр. акад. друкарства, 2011. 320 с.

3. Закон України «Про авторське право та суміжні права» №3792-XII від 23.12.1993 р. Офіиійний вебсайт Верховної Ради Украӥни. URL: https://zakon.rada.gov.ua/laws/show/3792-12\#Text

4. Закон України «Про видавничу справу» № 318/97-ВР від 05.06.1997 р. Офіиійний вебсайт Верховної Ради Украӥни. URL: https://zakon.rada.gov.ua/laws/show/318/97-\%D0\%B2\%D1\%80

5. Закон України «Про державну підтримку книговидавничої справи в Україні» № 601IV від 06.03.2003 p. Офіиійний вебсайт Верховної Ради України. URL: https://zakon.rada.gov.ua/laws/show/601-15

6. Закон України «Про друковані засоби масової інформації (пресу) в Україні» № 2782XII від 16.11 .1992 p. Офіиійний вебсайт Верховної Ради України. URL: https://zakon.rada.gov.ua/laws/show/2782-12

7. Закон України «Про інформацію» № 2657-XII від 02.10.1992 р. Офіційний вебсайт Верховної Ради України. URL: https://zakon.rada.gov.ua/laws/show/2657-12\#Text

8. Казак К. О. Господарсько-правове забезпечення видавничої діяльності в Україні : дис. ... канд. юрид. наук : 12.00.04. Х., 2016. 216 с.

9. Копистинська I. М. Функціонування книжкового ринку України в умовах переходу від планової до ринкової економіки. Науково-інформаційний вісник Івано-Франківського університету права імені Короля Данила Галицького. 2013. № 8. С. 295-301.

10. Овсієнко-Миронова Г. В. Організаційно-правові засади управління видавничою справою в Україні : автореф. ... канд. юрид. наук: 12.00.07. Х., 2006. 20 с.

11. Постанова Верховної Ради України № 695-VII від 19.11.2013 р. «Про рекомендації парламентських слухань на тему: «Проблеми розвитку українського книговидавництва,книгорозповсюдження та перспективи підтримки книгочитання в Україні». Відомості ВРУ. 2014. № 22. С. 852.

12. Постанова Кабінету Міністрів України «Про затвердження Порядку визначення обсягу книжкової продукції державною мовою, підготовка, випуск та/або розповсюдження якої здійснюються вітчизняними видавництвами i підприємствами розповсюдження книжкової продукції, для укладення договорів оренди приміщень» №597 від 17.06.2009 р. Офіиійний вебсайт Верховної Ради України. URL: https://zakon.rada.gov.ua/laws/show/597-2009-\%D0\%BF\#Text

13. Розпорядження Кабінету Міністрів України «Про схвалення Концепції Державної цільової національно-культурної програми популяризації вітчизняної видавничої продукції та читання на 2014-2018 роки» № 257-р від 10.04.2013 р. Офіиійний вебсайт Верховної Ради України. URL: https://zakon.rada.gov.ua/laws/show/257-2013-\%D1\%80\#Text

14. Рябчук С. Книговидання i держава: у пошуках стратегії. Міжнародний фонд «Відродження». 2009. 21 жовтня. 12 с. URL: https://cutt.ly/BjvCbqr

15. Садовська А. Державне регулювання розвитку книговидання як складова формування єдиного гуманітарного простору України. Ефективність державного управління. 2013. Вип. 37. C. 225-234.

16. Скленар I. Проблеми національного книговидання у сучасний період. Записки Львівської національної наукової бібліотеки Украӥни імені В. Стефаника. 2014. Вип. 6. С. 141-150. 
17. Шендерівська Л. П. Розвиток підприємств видавничо-поліграфічної галузі. Інтелект XXI. 2014. № 3. С. 72-77.

\section{References:}

1. Myhajlova, Yu. O. (Eds.) (2019). Aktualni problemy rynku knyzhkovoyi produkciyi v Ukrayini v konteksti zavdan gumanitarnoyi polityky: analitychna zapyska [Actual problems of book production's market in Ukraine in the context of humanitarian policy objectives: an analytical note]. Oficijnyj veb-sajt NISD, April. Retrieved from https://niss.gov.ua/doslidzhennya/gumanitarniyrozvitok/aktualni-problemi-rinku-knizhkovoi-produkcii-v-ukraini-v [in Ukrainian].

2. Durnyak, B.V. et al. (2011). Standarty v poligrafiyi ta vydavnychij spravi: dovidnyk [Standards in printing and publishing sphere: a guidebook]. Lviv: Vyd-vo Ukr. akad. drukarstva [in Ukrainian].

3. Zakon Ukrayiny «Pro avtorske pravo ta sumizhni prava» [Law of Ukraine "On Copyright and Related Rights”] № 3792-XII vid 23.12.1993 r. (1993, December 23). Oficijnyj vebsajt Verxovnoyi Rady Ukrayiny. Retrieved from https://zakon.rada.gov.ua/laws/show/3792-12\#Text [in Ukrainian].

4. Zakon Ukrayiny «Pro vydavnychu spravu» [Law of Ukraine "On Publishing activity"]№ 318/97-VR vid 05.06.1997 r. (1997, June 5). Oficijnyj vebsajt Verxovnoyi Rady Ukrayiny. Retrieved from https://zakon.rada.gov.ua/laws/show/318/97-\%D0\%B2\%D1\%80 [in Ukrainian].

5. Zakon Ukrayiny «Pro derzhavnu pidtrymku knygovydavnychoyi spravy v Ukrayini» [Law of Ukraine "On state support of book publishing in Ukraine”] № 601-IV vid 06.03.2003 r. (2003, May 6). Oficijnyj vebsajt Verxovnoyi Rady Ukrayiny. Retrieved from https://zakon.rada.gov.ua/laws/show/601-15 [in Ukrainian].

6. Zakon Ukrayiny «Pro drukovani zasoby masovoyi informaciyi (presu) v Ukrayini» [Law of Ukraine "On Printed Mass Media (Press) in Ukraine”] № 2782-XII vid 16.11.1992 r. (1992, November 16). Oficijnyj vebsajt Verxovnoyi Rady Ukrayiny. Retrieved from https://zakon.rada.gov.ua/laws/show/2782-12 [in Ukrainian].

7. Zakon Ukrayiny «Pro informaciyu» [Law of Ukraine "On Information"] № 2657-XII vid 02.10.1992 r. (1992, October 2). Oficijnyj vebsajt Verxovnoyi Rady Ukrayiny. Retrieved from https://zakon.rada.gov.ua/laws/show/2657-12\#Text [in Ukrainian].

8. Kazak, K. O. (2016). Gospodarsko-pravove zabezpechennya vydavnychoyi diyalnosti v Ukrayini [Economic and legal support of publishing activity in Ukraine]. Candidate's thesis. Kharkiv [in Ukrainian].

9. Kopystynska, I. M. (2013). Funkcionuvannya knyzhkovogo rynku Ukrayiny v umovax perexodu vid planovoyi do rynkovoyi ekonomiky [Functioning of the book market of Ukraine in the conditions of transition from planned to market economy]. Naukovo-informacijnyj visnyk IvanoFrankivskogo universytetu prava imeni Korolya Danyla Galyczkogo, 8, 295-301 [in Ukrainian].

10. Ovsiyenko-Myronova, G. V. (2006). Organizacijno-pravovi zasady upravlinnya vydavnychoyu spravoyu v Ukrayini [The organizational principles of management of publishing activity in Ukraine]. Extended abstract of candidate's thesis. Kharkiv [in Ukrainian].

11. Postanova Verxovnoyi Rady Ukrayiny № 695-VII vid 19.11.2013 r. «Pro rekomendaciyi parlamentskyx sluxan na temu: «Problemy rozvytku ukrayinskogo knygovydavnycztva,knygorozpovsyudzhennya ta perspektyvy pidtrymky knygochytannya $\mathrm{v}$ Ukrayini» [Resolution of the Verkhovna Rada of Ukraine № 695-VII of 19.11.2013 "On the recommendations of the parliamentary hearings on the topic:"Problems of development of Ukrainian 
book-publishing, books'distribution and prospects for supporting book-reading in Ukraine"] (2014, . № 22). Vidomosti VRU, 22, p. 852. [in Ukrainian].

12. Postanova Kabinetu Ministriv Ukrayiny «Pro zatverdzhennya Poryadku vyznachennya obsyagu knyzhkovoyi produkciyi derzhavnoyu movoyu, pidgotovka, vypusk ta/abo rozpovsyudzhennya yakoyi zdijsnyuyutsya vitchyznyanymy vydavnycztvamy i pidpryyemstvamy rozpovsyudzhennya knyzhkovoyi produkciyi, dlya ukladennya dogovoriv orendy prymishhen» [Resolution of the Cabinet of Ministers of Ukraine "On approval of determining for Determining the volume of books' production in the state language, preparation, production and/or distribution which are carried out by domestic publishers and books' distribution enterprises, for concluding lease agreements] № 597 vid 17.06.2009 r. (2009, June 17). Oficijnyj vebsajt Verxovnoyi Rady Ukrayiny. Retrieved from https://zakon.rada.gov.ua/laws/show/597-2009-\%D0\%BF\#Text [in Ukrainian].

13. Rozporyadzhennya Kabinetu Ministriv Ukrayiny «Pro sxvalennya Koncepciyi Derzhavnoyi cilovoyi nacionalno-kulturnoyi programy populyaryzaciyi vitchyznyanoyi vydavnychoyi produkciyi ta chytannya na 2014-2018 roky» [Resolution of the Cabinet of Ministers of Ukraine "On approval of the Concept of the state target national-cultural program of popularization of national publishing products and reading for 2014-2018"] № 257-r vid 10.04.2013 r. (2013, April 10). Oficijnyj vebsajt Verxovnoyi Rady Ukrayiny. Retrieved from https://zakon.rada.gov.ua/laws/show/257-2013-\%D1\%80\#Text [in Ukrainian].

14. Ryabchuk, S. (2009). Knygovydannya i derzhava: u poshukax strategiyi [Book publishing and the state: in search of strategy]. Mizhnarodnyj fond «Vidrodzhennya», September 21, 12 p. Retrieved from https://cutt.ly/BjvCbqr [in Ukrainian].

15. Sadovska, A. (2013). Derzhavne regulyuvannya rozvytku knygovydannya yak skladova formuvannya yedynogo gumanitarnogo prostoru Ukrayiny [State regulation of the development of book publishing as a component of the formation of a single humanitarian space of Ukraine]. Efektyvnist derzhavnogo upravlinnya,. 37, 225-234. [in Ukrainian].

16. Sklenar, I. (2014). Problemy nacionalnogo knygovydannya u suchasnyj period [Problems of national book publishing in the modern period]. Zapysky Lvivskoyi nacionalnoyi naukovoyi biblioteky Ukrayiny imeni $V$. Stefanyka, 6, 141-150. [in Ukrainian].

17. Shenderivska, L. P. (2014). Rozvytok pidpryyemstv vydavnycho-poligrafichnoyi galuzi [Development of enterprises of the publishing and printing industry]. Intelekt XXI, 3, 72-77. [in Ukrainian]. 